\title{
Practice and Research on Cultivating English Ability of Music Majors Students taking English Musical Movies as Carriers
}

\author{
Jia Gao, Chunmei Yu* \\ Public Foreign Language Education College, Beihua University, No \\ 3999 Binjiangdong Road Jilin City, Jilin Province, 132013
}

\begin{abstract}
Most music major students are committed to their professional knowledge learning and skills development and these students have ignored or even give up the study of cultural disciplines. It is particularly prominent in the study of English and their general English level is very low. The English music film can help students be familiar with the British and American accents, help students improve their listening comprehension and consolidate the English grammar, syntax knowledge and other aspect. Therefore, this paper discusses using English music movies to improve students' English learning ability.
\end{abstract}

Keywords: practice, research, music majors, English competence, English musical movies, carrier

\section{Introduction}

Although the English teaching reform of non-art majors in the university is in full swing, many English subjects only concern ordinary college students in order to improve their English comprehensive ability, but neglect a special small group music majors. In the professional knowledge, we should believe that they have higher than we have musical talent and potential, but when it comes to cultural subjects, especially English learning, many music students will feel it is a very troublesome "work ", It seems than" immortal ". Compared with other students, the students who study music have obvious deficiencies in English foundation, 
interest and self - confidence, which leads to their negative attitude towards learning English. From the results of learning English, many music students are difficult to meet the requirements of the Ministry of Education and the school requirements. Although many colleges and universities on the teaching and reform of college English in full swing, but the music students of English learning can not be ignored, they are also a harmonious society construction and development of an important group. It is necessary to further study the public English course and teaching of music majors and find out the weaknesses of current music students' learning English and try to find out their interest, motive and way of learning English, find out the suitable English courses and effective teaching methods, The English level, strive to become outstanding contemporary college students, for music after life lay a solid foundation.

Nowadays, the problems of college students in Chinese universities in English study are lack of interest in learning and their English listening and speaking skills are poor. College English teachers and students are constantly searching for effective ways to solve this problem. As we all know, the best way to learn the language is to provide a good language environment for learners, the most direct way is to live in the language of the mother country, but because of conditions, most people can only learn foreign languages. In the country to learn English, English video data to a certain extent make up for not long-term living abroad in this shortcoming, its material comes from the colourful life, involving a wide range of content. First, the English original film reflects all aspects of social life, the audience into a completely different with the local environment of the world, students can be immersed into it to feel its language, thinking and culture; Second, each of the In the different themes and scenes, students can learn different language expression methods; again, the film and television drama is a typical life of the art form, with the daily life of the oral expression of close fit, It can be said that the latter refraction, drama and language in the middle of life to form a link, so that language from life and serve the life. Therefore, the use of film and television drama resources for English teaching, you can break through the limitations of teaching materials for the vast majority of students do not have the conditions to go abroad to study music professional students can also be exposed to the natural language of English conversation environment, greatly enriched learners in all aspects knowledge, thus significantly improve the teaching efficiency and effectiveness.

\section{The students' English learning situation of musical major}

First, the vast majority of music students lack the interest and confidence in English learning. In terms of interest in learning, according to past and current general knowledge and social facts, their work after graduation depends on the degree of English is far less than other professional students, so a lot of music students relaxed English learning, psychological relaxation caused Their interest in learning English is significantly weaker than other non-art undergraduate students. Interest is the best teacher to learn English, the survey found that about 
67\% of music students feel that English for them Of the future without any relationship. Interests represent deep-seated hobbies when individuals are attracted to what they really care about. Interest is composed of internal and external factors: one is the internal needs of the individual, the second is the outside world or things have to meet the individual needs of the value. With the development of modern educational philosophy, "Appreciation Education" came into being, which promoted the students' interest in learning. And music students in learning English is obviously not enough interest, the traditional long-term teaching model, the basis of English students of music students have a sense of helplessness in English classes, they are in English or most of the English teaching organizations often appear silly class, At a loss. Which led to the students can not meet the learning requirements.

Second, most students have a poor English foundation. There is no doubt that musicians have learned their professional knowledge with ease because their previous foundations and interests have led to their seriousness, but because of their lack of systematic study of scientific and cultural knowledge at the secondary level, their natural disciplines Of the results and other non-art students are very different, especially in English. According to my teaching experience: many of them students' pronunciation is not accurate, the basic grammar knowledge model, the basic vocabulary is not up to the requirements, do not know how to memorize the word method. Therefore, whether it is spoken language, written choice of vocabulary, or reading comprehension is a problem, not to mention writing, it can be said that their high school basic knowledge of the English institutions did not build up into the university, the face of graduation And social competitive pressures, for their basic knowledge of English need to "make up" the.

Third, most students lack the ability to interpret text. Readability refers to the difficulty of learners, suitability refers to the content of teaching materials should be interesting and credible, and can be developed means that learners through learning materials to learn reading skills and strategies. Teaching material is for the purpose of teaching, is an important source of teaching and learning, is the most basic curriculum resources.

\section{The impact of English music films on the English proficiency of music majors}

English movies allow students to learn English from the soundtrack to learn English as a native speaker how to use the native language. For many students learning English, beautiful melodies and wonderful British and American film lines and lyrics conducive to the students in a relaxed state of mind to learn the language. The information in the film through the visual, auditory, operation, transmission to the brain centre and establish a signal link, on this basis to improve the language ability. Those in the watch in the memory of the film in the dialogue, and real life, once the scene coincides with the scene, will induce the 
brain Rapid response and accelerated memory, the formation of the language after the deepening of the sense of language can be seen in English as a teaching aid means the feasibility and superiority.

The use of English movie lines and vocabulary to help students understand the words and sentences, and ask students to complete the sentence to answer. The teacher chooses a phrase or sentence from the film and lets the student select the same phrase or sentence on the answer sheet. The teacher asks the student to answer the question after reading the film. The students can use their own point of view to answer questions raised by teachers to develop students' attention and understanding English film for students listening training English film characters are using the normal speed of speech Speaking, which makes students accustomed to and can understand and master English spoken English commonly used in the abbreviation, weakening and other pronunciation features, gradually familiar with the British and American accents students exposure to pure voice, natural speed, from different countries of the English country's accent and style, The "written language of the bondage. English film for students to write a sense of the students after watching a complete English film, the teacher asked the students to understand the social background of the film, practice writing a movie view. This activity will help students to learn grammar, syntax, lexical and temporal knowledge and improve their writing skills.

Teachers according to the film content, let the students play the characters in the original sound film. English film role-playing, students' ability of thinking, speaking and make use of English to express ideas constantly improve the ability of students to overcome the introverted personality, to carry out mutual learning. English film role-playing, improve student pronunciation accuracy, students find language sense; review classroom knowledge of English, students apply their knowledge, knowledge and action. Teachers of the students' education is not only knowledge-based, but also a complete personality education and comprehensive quality improvement.

In the process of allowing music majors to watch English music films, teachers should not only select several English original films or dramas for each semester, but also explain the cultural background and language difficulties. Otherwise, if the discussion is not done after the discussion and practice, leading to students in the film to observe the interest in the film has not been further extended, and ultimately did not make the English film and television appreciation to play some role. Therefore, I combined their own teaching practice recommendations, English film and television appreciation is not simply watch the film, but should do more research and more preparatory work.

\section{Conclusion}

Music students can not only learn the language and music knowledge but also make the students appreciate the course through the English film, change the students' perception of traditional English learning, and change from passive learning to active learning. So that students can enhance their English practical application capacity and to further enhance cross-cultural awareness to achieve a 
deep understanding of English language and culture, and ultimately achieve a gradually improving of English comprehensive level.

\section{Acknowledgements}

The research work was supported by [2015] 75: Education and Science Project, Jilin Contract. NO. 104115003

\section{References}

[1] Tang Weihong. Using English Movies to Promote College English Listening and Speaking Teaching. Science, Education and Culture Exchange, 55(12), pp.68-70, 2011

[2] Young evening star. Psychological Adjustment of College Students' English Learning in Art. Foreign Language Teaching, 8 (5), pp.87- 91, 2013

[3] Guo Yingchun. A Probe into English Majors' Motivation in English Learning. College English 12(10), pp. 18- 20, 2012

[4] Jia Xiaojuan. Current Situation and Enlightenment of Artistic and Sports Students' English Teaching in Comprehensive Universities. Cultural and Educational Information, 9(6), pp.58- 61, 2011

[5] Li Ying. On the art of college English teaching reform thinking. Journal of Xiaogan University, 8(4), pp.85-87, 2014 